\title{
Growth Parameter Differences between Populations of Blue Grama
}

\author{
M.J. SAMUEL
}

\begin{abstract}
Samples of blue grama were obtained from disturbed and undisturbed areas of native rangeland in southeast Wyoming. Assumed 'slow-spread' populations were selected along a 50-year-old plowline from blue grama sod which had spread only a few centimeters into the plowed area. Assumed 'fast-spread' populations were selected from large plants within the plowed area. Control populations were selected at random from the undisturbed native range. Plants from 15 populations were grown in a dryland, uniform garden where basal spread was measured to determine if there were differences in rate of spread between populations of blue grama. Herbage production, plant height, and phenology were also compared. By the end of the second and fourth seasons of growth in the uniform garden, the fast-spread populations had spread 21 and $20 \%$ more than the slow-spread populations. The random populations were 17 and $11 \%$ larger than the slow-spread populations during the same year. The fast-spread and random populations were not different.
\end{abstract}

Throughout the Central Great Plains there are many marginal areas which were cultivated and then, when drought conditions prevailed, allowed to return to native vegetation. Costello (1944) detailed the steps of natural revegetation of abandoned plowed land (old fields) in northeastern Colorado. He stated that in some instances blue grama [Bouteloua gracilis (H.B.K.) Lag ex Griffiths] appeared on old fields during the initial stage of revegetation, although its abundance was quite low and its presence may have been overlooked. Blue grama may not become dominant in the vegetation until 20-50 years after abandonment. Tomanek et al.

\footnotetext{
Author is botanist, ISSDA Agriculture Research Service, High Plains Grasslands Research Station, 8408 Hildreth Road, Cheyenne, Wyo. 82009.

Manuscript accepted October 15, 1984.
}

(1955) reported that blue grama revegetated an abandoned field slowly. Blue grama made up 6.6 and $11.3 \%$ of the herbage production by weight after 23 and 33 years, respectively, of natural succession compared with $26.8 \%$ blue grama on native rangeland. If the disturbance was from a single cultivation, vegetative remnants of some of the native plants revegetated the area after abandonment (Costello 1944, Hyder et al. 1971). Hyder et al. (1971) reported 40-year-old plowlines which were still visiblc because the furrow next to the blue grama sod was straight and distinct.

Several authors (Riegel 1940, Mueller 1941, McMillian 1956, and Green and Goetz 1973) have reported variability within several growth parameters of blue grama plant material which was collected throughout the Great Plains.

The objective of this experiment was to determine if there might be differences in rate of spread between blue grama populations taken from sod which had spread minimally along a plowline, compared with populations taken from plants within the disturbed area which had spread considerably since the disturbance.

\section{Materials and Methods}

In 1926 approximately 15 ha of semiarid rangeland were plowed and planted to an unknown hay crop (Current 1978) on what is now known as the High Plains Grasslands Research Station northwest of Cheyenne, Wyo. This plowed area was allowed to return to native vegetation in 1927 . Because it was not fenced, the previously plowed land has been grazed along with the adjacent native range. Current (1978) estimated that yearlong grazing pressure ranged between 0.3 to $2.4 \mathrm{ha} / \mathrm{AUM}$ since 1928 . It is probable that the grazing season was less than yearlong and therefore the grazing pressure was less. In 1976 part of the plowline was still 
visible as a straight line because of the difference in botanical composition between the 2 sides of the plowline. Some blue grama plants had not spread more than a few centimeters from the unplowed area into the plowed area while others had spread to form patches of up to a meter in diameter within the plowed area. Many of these patches of blue grama were in rows which suggests most plants, that had not been destroyed by plowing, probably originated from remnants between furrows. Nevertheless, some plants could have established from seed.

In October of 1976, 3.8-cm diameter plugs of blue grama sod were collected within section 8 (T-14-N; R-67-W). Samples were taken at 5 separate places along the plowline in the unplowed native rangeland from plants which were adjacent to, but had not grown into, the plowed area. These 5 samples were assumed to be from material which was slow to spread. Another 5 samples were obtained from 5 separate large patches of blue grama in the plowed area. The material in these large patches was assumed to be fastspreading. A third set of samples was obtained from 5 places selected at random from the nearby native rangeland. These latter samples were used as controls. The 15 samples, each consisting of 9 separate plugs, will be referred to as populations because the material may not be genetically identical within each sample, particularly those from along the plowline or from the native rangeland.

Plugs were grown in the greenhouse during the winter of 197677. In April plant material from these plugs was divided so that each prospective plant started from a tiller with 1 rooted node. These plants were grown in pots in the greenhouse. In early June, 16 plants were selected randomly from each population and set into a dryland plot area with a randomized complete block design. The soil was a Wheatridge fine loam over sand or sandy-skeletal, a member of the mixed mesic family of Aridic Argiustolls (Stevenson et al. 1984). Plants were set on 107-cm centers. Plants were watered when planted but received no additional irrigation. The 40-year average annual precipitation was $37 \mathrm{~cm}$ with $70 \%$ occurring between 30 September and 1 April. Precipitation was 96, 67, 96,113 , and $116 \%$ of normal for the 12 months ending in August of 1977 through 1981, respectively. Weeds were removed from the plot area regularly. Of the 240 plants set into the garden, 2 did not survive. One plant was later damaged by a runaway horse and was deleted from data taking. Values for these missing plants were estimated (Steel and Torrie 1960). Means were separated using
Tukey's w procedure $(P<0.05)$

Data collection was started in 1978 and continued through 1981 Not all measurements were taken in all years. Basal area was estimated with the use of a grid (Hart 1965). The grid was calibrated by counting intersections on a known area to get a conversion factor of points to square centimeters. In the field, the grid was placed on top of a plant from which the herbage had been harvested. Squares of 5 by 5 intersections on the grid were painted different colors for faster counting. An intersection was counted when it was within the rooted parimeter of the plant. The number of grid intersections was averaged from 5 and 3 grid placements per plant in 1978 and 1980 , respectively.

Basal area was of primary interest, but other measurements were taken on these plants. Phenological observations were made 3 times weekly to document boot stage, heading, and anthesis in each of the 4 years. Anethesis date was analyzed because it was the most objective phenological stage of development. Vegetative height was measured, before the boot stage, from ground level to the tip of the extended longest leaf in 1981. Reproductive height was measured, after anthesis, from ground level to the tallest flowering axis during 1978 and 1981 . Herbage was cut to ground level to obtain herbage production in late August or early September of 1978 and 1980.

\section{Results and Discussion}

Basal area of the 15 populations is shown in Table 1. Populations were combined into their assumed fast, slow, and random rate-of-spread groups. The analysis of variance showed that significant differences occurred between the spread groups. In 1978 and 1980 , respectively, the slow-spread populations averaged 81 and $264 \mathrm{~cm}^{2}$ and were slower spreading than the fast-spread populations ( 98 and $317 \mathrm{~cm}^{2}$ ) or the random populations $\left(95\right.$ and $\left.293 \mathrm{~cm}^{2}\right)$. In 1978 the mean basal area was $91 \mathrm{~cm}^{2}$. When the means of the populations were compared, population 9, a fast spreader, spread more than populations 1 and 8 , which were both slow spreaders. There was a difference of $37 \mathrm{~cm}^{2}$ between the fastest and slowest spreading populations ( 77 and $114 \mathrm{~cm}^{2}$, respectively). In 1980 the mean basal area was $292 \mathrm{~cm}^{2}$. Population 10 had the largest basal area. It spread faster than populations 5 and 15 , both assumed to be slow spreaders. The range of basal areas for 1980 was from 231 to $345 \mathrm{~cm}^{2}$, a difference of $114 \mathrm{~cm}^{2}$. For both years, when the populations were placed in order of decreasing basal area, the

Table 1. Basal area, herbage weight and herbage weight per unit area of blue grama populations and rate of spread groups. ${ }^{1}$

\begin{tabular}{|c|c|c|c|c|c|c|c|}
\hline \multirow[b]{2}{*}{ Assumed rate of spread } & \multirow[b]{2}{*}{ Population } & \multicolumn{2}{|c|}{ Basal Area } & \multicolumn{2}{|c|}{ Herbage $\mathrm{Wt}$} & \multicolumn{2}{|c|}{ Herbage wt/unit area } \\
\hline & & 1978 & 1980 & 1978 & 1980 & 1978 & 1980 \\
\hline & & $\ldots \ldots$ & $\ldots \ldots$ & ..........8 & $\ldots \ldots \ldots$ & $\ldots$ & $\ldots . . .$. \\
\hline \multirow[t]{6}{*}{ Fast } & 7 & $95 \mathrm{ab}$ & $311 \mathrm{ab}$ & $27.6 \mathrm{abc}$ & $81.6 \mathrm{de}$ & $.29 \mathrm{~b}$ & $.27 \mathrm{e}$ \\
\hline & 9 & $114 \mathrm{a}$ & $308 \mathrm{ab}$ & $41.1 \mathrm{a}$ & $96.8 \mathrm{bcdc}$ & $.36 \mathrm{ab}$ & .30 cde \\
\hline & 10 & $97 \mathrm{ab}$ & $345 \mathrm{a}$ & $32.9 \mathrm{abc}$ & $141.6 \mathrm{a}$ & $.35 \mathrm{ab}$ & $.42 \mathrm{ab}$ \\
\hline & 12 & $91 \mathrm{ab}$ & $293 \mathrm{abcd}$ & $36.2 \mathrm{abc}$ & $109.6 \mathrm{abcd}$ & $.39 \mathrm{a}$ & $.38 \mathrm{abcd}$ \\
\hline & 13 & $94 \mathrm{ab}$ & $326 \mathrm{ab}$ & $33.3 \mathrm{abc}$ & $91.5 \mathrm{cde}$ & $.35 \mathrm{ab}$ & $.28 \mathrm{e}$ \\
\hline & Mean & $98 X$ & $317 X$ & $34.2 \times$ & $104.2 X$ & $.35 \mathrm{X}$ & $.33 \mathrm{X}$ \\
\hline \multirow[t]{6}{*}{ Random } & 3 & $96 \mathrm{ab}$ & $277 \mathrm{abcd}$ & $23.9 \mathrm{bc}$ & $86.6 \mathrm{de}$ & $.26 \mathrm{~b}$ & $.32 \mathrm{cde}$ \\
\hline & 4 & $95 \mathrm{ab}$ & $306 \mathrm{abc}$ & $29.4 \mathrm{abc}$ & 104.6 bcde & $.35 \mathrm{ab}$ & .35 bcde \\
\hline & 6 & $98 \mathrm{ab}$ & 305 abcd & $31.0 \mathrm{abc}$ & $93.2 \mathrm{cde}$ & $.33 \mathrm{ab}$ & $.31 \mathrm{cde}$ \\
\hline & 11 & $102 a b$ & $320 \mathrm{ab}$ & $36.6 \mathrm{ab}$ & $126.4 \mathrm{abc}$ & $.35 \mathrm{ab}$ & $.39 \mathrm{abc}$ \\
\hline & 14 & $83 \mathrm{ab}$ & $257 \mathrm{bcd}$ & $28.9 \mathrm{abc}$ & $76.0 \mathrm{de}$ & $.36 \mathrm{ab}$ & .30 cde \\
\hline & Mean & $95 \times$ & $293 X$ & $30.0 \mathrm{XY}$ & $97.4 \times$ & $.33 \times$ & $.34 X$ \\
\hline \multirow[t]{6}{*}{ Slow } & 1 & $78 \mathrm{~b}$ & $292 \mathrm{abcd}$ & $22.0 \mathrm{c}$ & $88.8 \mathrm{de}$ & $.29 \mathrm{~b}$ & $.32 \mathrm{cde}$ \\
\hline & 2 & $87 \mathrm{ab}$ & $292 \mathrm{abcd}$ & $29.6 \mathrm{abc}$ & 92.2 cde & $.35 \mathrm{ab}$ & .32 cde \\
\hline & 5 & $80 \mathrm{ab}$ & $233 \mathrm{~cd}$ & $24.5 \mathrm{bc}$ & $72.1 \mathrm{e}$ & $.30 \mathrm{~b}$ & $31 \mathrm{cde}$ \\
\hline & 8 & $77 \mathrm{~b}$ & $271 \mathrm{abcd}$ & $35.0 \mathrm{abc}$ & $129.7 \mathrm{ab}$ & $.44 \mathrm{a}$ & $.47 \mathrm{a}$ \\
\hline & 15 & $85 \mathrm{ab}$ & $231 \mathrm{~d}$ & $29.4 a b c$ & $81.5 \mathrm{de}$ & $.36 \mathrm{ab}$ & .35 bcde \\
\hline & Mean & $81 \mathrm{Y}$ & $264 Y$ & $28.1 \mathrm{Y}$ & $92.9 \times$ & $.35 X$ & $.36 \mathrm{X}$ \\
\hline
\end{tabular}

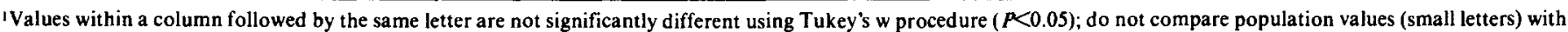
mean values (capital letters). 
Table 2. Vegetative height, reproduction height and anthesis dates of blue grama populations and rate of spread groups.'

\begin{tabular}{|c|c|c|c|c|c|c|c|c|}
\hline \multirow{2}{*}{$\begin{array}{l}\text { Assumed rate } \\
\text { of spread }\end{array}$} & \multirow[b]{2}{*}{ Population } & \multirow{2}{*}{$\begin{array}{l}\begin{array}{c}\text { Vegetative } \\
\text { height }\end{array} \\
1981\end{array}$} & \multicolumn{2}{|c|}{ Reproductive Height } & \multicolumn{4}{|c|}{ Anthesis Date } \\
\hline & & & 1978 & 1981 & 1978 & 1979 & $1980^{2}$ & 1981 \\
\hline \multirow{7}{*}{ Fast } & & $\ldots \mathrm{cm} \ldots$ & & & & …........J & Day....... & \\
\hline & 7 & $13.1 \mathrm{bc}$ & $43.0 \mathrm{abc}$ & $40.7 \mathrm{bcd}$ & $196 a$ & $191 \mathrm{ab}$ & $183 \mathrm{a}$ & $177 \mathrm{a}$ \\
\hline & 9 & $13.9 \mathrm{bc}$ & $39.4 \mathrm{bc}$ & $40.7 \mathrm{bcd}$ & $203 \mathrm{~cd}$ & $197 \mathrm{c}$ & $202 \mathrm{~cd}$ & $187 \mathrm{e}$ \\
\hline & 10 & $13.3 \mathrm{bc}$ & $43.7 \mathrm{abc}$ & $41.9 \mathrm{bcd}$ & $199 \mathrm{abc}$ & $191 \mathrm{ab}$ & $187 \mathrm{abc}$ & 184 bcde \\
\hline & 12 & $14.3 \mathrm{bc}$ & $43.6 \mathrm{abc}$ & $46.0 \mathrm{abc}$ & $200 \mathrm{abcd}$ & $193 \mathrm{abc}$ & $189 \mathrm{abc}$ & 180 abcd \\
\hline & 13 & $14.1 \mathrm{bc}$ & $47.1 \mathrm{a}$ & $45.7 \mathrm{bcd}$ & $200 \mathrm{abcd}$ & $192 \mathrm{ab}$ & $187 \mathrm{abc}$ & $179 \mathrm{abc}$ \\
\hline & Mean & $13.8 \mathrm{X}$ & $43.4 \times$ & $43.0 \mathrm{Y}$ & $200 X$ & $193 \times$ & $190 X$ & $182 X$ \\
\hline \multirow[t]{6}{*}{ Random } & 3 & $11.7 \mathrm{c}$ & $43.9 \mathrm{abc}$ & $45.2 \mathrm{bcd}$ & $197 \mathrm{ab}$ & $190 \mathrm{a}$ & $186 \mathrm{ab}$ & $178 \mathrm{ab}$ \\
\hline & 4 & $12.4 \mathrm{c}$ & $43.0 \mathrm{abc}$ & $46.1 \mathrm{abc}$ & $204 \mathrm{~d}$ & $195 \mathrm{bc}$ & 199 bcd & 182 abcde \\
\hline & 6 & $11.2 \mathrm{c}$ & $42.3 \mathrm{abc}$ & $39.4 \mathrm{~cd}$ & $201 \mathrm{bcd}$ & $192 \mathrm{ab}$ & $188 \mathrm{abc}$ & $179 \mathrm{abc}$ \\
\hline & 11 & $12.8 \mathrm{bc}$ & $44.1 \mathrm{abc}$ & $47.8 \mathrm{ab}$ & $201 \mathrm{bcd}$ & 193 abc & $190 \mathrm{abc}$ & 183 abcde \\
\hline & 14 & $12.1 \mathrm{c}$ & $43.3 \mathrm{abc}$ & $43.6 \mathrm{bcd}$ & $200 \mathrm{abcd}$ & $193 a b c$ & 194 abcd & 182 abcde \\
\hline & Mean & $12.0 \mathrm{Y}$ & $43.3 \mathrm{X}$ & $44.4 X Y$ & $201 X$ & $192 X$ & $191 X$ & $181 X$ \\
\hline \multirow[t]{6}{*}{ Slow } & 1 & $13.4 \mathrm{bc}$ & $45.0 \mathrm{ab}$ & 44.3 bcd & $198 \mathrm{ab}$ & $192 a b$ & $189 \mathrm{abc}$ & 183 abcde \\
\hline & 2 & $15.6 \mathrm{ab}$ & $42.4 \mathrm{abc}$ & $44.4 \mathrm{bcd}$ & $203 \mathrm{~cd}$ & 195 bc & $209 \mathrm{~d}$ & 185 cde \\
\hline & 5 & $11.3 \mathrm{c}$ & $38.7 \mathrm{c}$ & $38.0 \mathrm{~d}$ & $200 \mathrm{abcd}$ & $194 \mathrm{abc}$ & 191 abc & 184 bcde \\
\hline & 8 & $18.4 \mathrm{a}$ & $44.4 \mathrm{abc}$ & $53.8 \mathrm{a}$ & 202 bcd & $194 \mathrm{abc}$ & 196 abcd & $186 \mathrm{de}$ \\
\hline & 15 & $12.5 \mathrm{bc}$ & $43.4 \mathrm{abc}$ & $47.7 \mathrm{ab}$ & 202 bcd & $194 \mathrm{abc}$ & $188 \mathrm{abc}$ & $186 \mathrm{de}$ \\
\hline & Mean & $14.2 \mathrm{X}$ & $42.8 \times$ & $45.6 \times$ & $201 \times$ & $194 X$ & $195 \times$ & $185 \mathrm{Y}$ \\
\hline
\end{tabular}

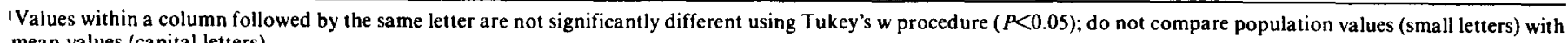
mean values (capital letters).

2Ten plants which did not bloom by day 234 were assigned a 240 Julian day tor purposes of analysis.

assumed fast-spread populations were in the top half of the list and the assumed slow-spread populations were on the bottom half of the list. The populations selected at random from the undisturbed native range were scattered throughout the list.

The variation in basal area within each group was also evaluated. In 1978 there were no differences in rate of spread within the fast, slow, or random groups. In 1980 there were no differences in basal area within the fast-spread or the random groups, but within the slow-spread group, populations 1 and 2 had larger basal areas than populations 5 and 15. Population 8 was intermediate.

When herbage production was analyzed (Table 1), the fast-and slow-spread populations were distributed throughout the range of values and not clustered at the top and bottom, respectively, as they were for the basal area data. In 1978 population 9 produced more herbage than populations 5,3 , and 1 , but in 1980 population 9 was the same as the latter and population 10 was more productive than 11 populations including 5, 3, and 1 . In 1978 the slow spreaders produced less herbage than the fast spreaders. But in 1980 the differences were only between populations and were not significant among spread-rate groups.

Because herbage production per plant is obviously influenced by basal area ( $r=0.693$ and 0.998 for 1978 and 1980 , respectively), the herbage weight per unit of basal area, $\mathrm{g} / \mathrm{cm}^{2}$, was calculated and analyzed (Table 1). In 1978, populations 8 and 13 had higher production per unit area than populations 5, 7, 1, and 3. In 1980, population 8 had significantly more herbage per unit area, 0.47 $\mathrm{g} / \mathrm{cm}^{2}$, than 11 of the 14 populations. Grams per unit area was not correlated with basal area $(r=0.060$ and 0.117 for 1978 and 1980 , respectively) and did not differ significantly among spread-rate groups in either year.

Vegetative height was measured in 1981 (Table 2). Population 8 was taller vegetatively than 13 of the other 14 populations. The slow- and fast-spread groups were significantly taller than the random group.

The height of the tallest reproductive culm of each plant was measured after anthesis in 1978 and 1981 (Table 2). In 1978 only populations 13 and 5 were of different heights. There were no differences when grouped by rate of spread. In 1981, probably because of the abundant precipitation, there were many differences among the populations, but 13 and 5 were not different. In 1981 , the slow-spread group of populations was taller than the fast- spread. The random group was intermediate.

Anthesis date was the only variable measured in all 4 years of the study, 1978 through 1981 (Table 2). Unlike most other variables, the earliest blooming populations were early in all years and the late blooming populations always bloomed late. Populations 7 and 3 bloomed earlier than population 9 in all 4 years. Population 7 and population 9 are both fast spreaders. An analysis by growth rate showed no difference for 1978, 1979, and 1980. In 1981, however, the slow-spread populations were slower to reach anthesis than the fast-spread or random groups, probably because of the early bloom date in that year when 3 of the 4 slowest blooming populations were slow-spread populations.

Bloom date was influenced by weather. The average bloom date was $1 \mathrm{July,} 12 \mathrm{July,} 19 \mathrm{July}$ in 1981, 1979, and 1978, respectively. Ten plants did not bloom in 1980 . These 10 plants were in 4 different populations: 1 slow-spread, 1 fast-spread, and 2 random populations. The lack of summer precipitation in 1980 probably delayed the blooming for the year. Although precipitation was $113 \%$ of normal for the 12 months preceding sampling, precipitation was only $3 \%$ of normal in June and $64 \%$ of normal for June through August. Precipitation in 1981 was $122 \%$ above normal for January through June and $270 \%$ above normal in May. This high availablity of moisture probably resulted in the early bloom date for 1981. McMillian (1956), who transplanted blue grama from throughout Nebraska to a uniform garden in Lincoln, reported that antehesis dates varied approximately 2 weeks between the 2 years of his study and that the latest flowering clone was the same in both years.

\section{Conclusions}

Blue grama populations were found to be quite variable for several growth parameters. There is a difference in rate of spread among populations of blue grama, even when sampled within a small geographic area. The visibility of very old plowlines next to blue grama dominated native rangeland may be evidence of slow growing populations throughout the plains. Fast growing populations may be present where old plowlines have been obliterated. Some populations have a short growth habit and low forage production, while others have long, leafy stems and high forage production. Because rate of spread was not correlated with herbage production, a breeding program might develop a fast spreading, high yielding type. 


\section{Literature Cited}

Costello, David F. 1944. Natural revegetation of abandoned plowed land in the mixed prairie association of northeastern Colorado. Ecology. 25:312326.

Current, Francis B. 1978. Ecology of grazing on Wyoming shortgrass. MS Thesis. Univ. Wyoming, Laramie.

Green, Curits E., and Harold Goetz. 1973. Morphological variation in three ecotypes of Agropyron smithii Rydb. and Bouteloua gracilis (H.B.K.) Lag ex. Steud. North Dakota State Agr. Exp. Sta. Bull. 491.

Hart, Richard H. 1965. A miniature grid for estimating a rea of grass leaves. Agron. J. 57:634.

Hyder, D.N., A.C. Everson, and R.E. Bement. 1971. Seedling morphology and seeding failures with blue grama. J. Range Manage. 24:287-292.
McMillian, Calvin. 1956. Nature of the plant community. I. Uniform garden and light period studies of five grass taxa in Nebraska. Ecology. 37:330-340.

Mueller, Irene M. 1941. An experimental study of rhizomes of certain prairie plants. Ecol. Monogr. 11:165-188.

Riegel, Andrew. 1940. A study of the variations in the growth of blue grama grass from seed produced in various sections of the Great Plains region. Trans. Kans. Acad. Sci. 43:155-171.

Steel, Robert G.D., and James H. Torrie. 1960. Principles and procedures of statistics. McGraw-Hill Book Co. New York.

Stevenson, Abe, Robert E. Baumgartner, and Gerald E. Schuman. 1984. High Plains Grasslands Research Station, Cheyenne, Wyoming, Detailed Soil Survey. Wyoming Agr. Exp. Sta. Pub.

Tomanek, G.W., F.W. Albertson, and Andrew Riegel. 1955. Natural revegetation on a field abandoned for thirty-three years in central Kansas. Ecology. 36:407-412. 